\title{
Webinar: the New Way of Continued Medical Education
}

\author{
Amaresh Biradar ${ }^{1}$ iD \\ Received: 26 June 2020 / Accepted: 3 July 2020 / Published online: 17 July 2020 \\ (C) The Author(s) 2020
}

Sir,

Due to the recent outbreak of the Covid-19 pandemic and nationwide lockdown, there has been an upsurge use of virtual platforms to conduct classes, seminars, webinars, and continued medical education programs (CMEs). These platforms have also been used in every field like cooking classes, yoga classes, fitness, schools, colleges, and businesses. The virtual meeting platforms are also used in surgical fields as well to spread knowledge and science. The virtual platforms have an option of presenting a screen and thereby sharing the PowerPoint presentation. There is a two-way interaction with the audiences happening in real time.

Here, we have various reputed company platforms like Google Meet, [1] Zoom, [2] Microsoft Teams, [3] Cisco
Webex, [4] GoToMeeting, [5] YouTube, and Facebook. Platforms like YouTube and Facebook can be used for streaming to the audience and have a one-way video interaction. In these two platforms, the questions can be asked through the comments sections. The other platforms like Google Meet, Zoom, Microsoft Teams, Webex, and GoToMeeting have a two-way discussion with many participants. Most of the platforms need high-speed internet connectivity preferably $4 \mathrm{G}$ connections.

Table 1 shows the comparison of the various platforms.

All the features mentioned are as of May 15, 2020. It may change with time.

Table 1 Comparing various platforms of virtual platforms

\begin{tabular}{llllll}
\hline & Google Meet [1] & Zoom [2] & Microsoft Teams [3] & Cisco Webex [4] & GoToMeeting [5] \\
\hline Maxium participants & 250 & 1000 (paid version) & 250 & 200 & 250 \\
Separate app in mobile & Yes & Yes & Yes & Yes & Yes \\
Laptop & Chrome browser & Software & Software & Software & Software \\
User friendly & Easy & Easy & Difficult & Moderate & Easy \\
Recording option & Yes in paid version & Yes & Yes & Yes & Yes \\
Stream to YouTube & No & Yes & Yes & Rs: $1024[13.5 \$]$ & Rs: $910[12 \$]$ \\
Subscription price & Free and paid in G-Suite & Rs: $1138[15.5 \$]$ & Rs: $380[13.5 \$]$ &
\end{tabular}

Amaresh Biradar

docamaresh@gmail.com

1 Highborn Plastic Surgery Center, Sedam Road,

Kalaburagi, Karnataka 585105, India 


\section{Compliance with Ethical Standards}

Conflict of Interest The author declares that he has no conflict of interest.

Open Access This article is licensed under a Creative Commons Attribution 4.0 International License, which permits use, sharing, adaptation, distribution and reproduction in any medium or format, as long as you give appropriate credit to the original author(s) and the source, provide a link to the Creative Commons licence, and indicate if changes were made. The images or other third party material in this article are included in the article's Creative Commons licence, unless indicated otherwise in a credit line to the material. If material is not included in the article's Creative Commons licence and your intended use is not permitted by statutory regulation or exceeds the permitted use, you will need to obtain permission directly from the copyright holder. To view a copy of this licence, visit http://creativecommons.org/licenses/by/4.0/.

\section{References}

1. https://apps.google.com/meet/ Accessed 15 June 2020

2. www.zoom.us Accessed 15 June 2020

3. https://www.microsoft.com/en-in/microsoft-365/microsoft-teams/ group-chat-software Accessed 15 June 2020

4. https://www.webex.com/ Accessed 15 June 2020

5. https://www.gotomeeting.com/en-in Accessed 15 June 2020

Publisher's Note Springer Nature remains neutral with regard to jurisdictional claims in published maps and institutional affiliations. 